\title{
The First Record of The Archeoastronomical Bind Rune Associated with Petroglyphs in Danigala Circular Rock, Sri \\ Lanka
}

\author{
Aravinda Ravibhanu Sumanarathna ${ }^{1}$, Majda Aouititen ${ }^{2}$, Bernie Taylor ${ }^{3}$, Geeth Sameera ${ }^{4}$, Jinadasa \\ Katupotha $^{5}$, Aruna Bandara ${ }^{6}$ \\ ${ }^{1,2,3}$ Department of Research \& Innovation - South Asian Astrobiology \& Earth Sciences Research Unit of Eco
} Astronomy Sri Lanka, Colombo, Sri Lanka.

${ }^{2}$ Beijing Forestry University School of Ecology and Nature Conservation, Beijing, China.

${ }^{3}$ Before Orion, Portland, Oregon, United States of America.

${ }^{4}$ Geological Survey and Mines Bureau, 569 Epitamulla Road, Pita Kotte, Sri Lanka 10100.

${ }^{5}$ Department of Geography -University of Sri Jayewardenepura, Nugegoda, Sri Lanka

${ }^{6}$ Central Cultural Fund- Polonnaruwa, Sri Lanka.

Email: aravinda@ecoastronomy.edu.lk

\begin{abstract}
Danigala Rock is a unique geological site situated near Kandegama at Polonnaruwa district. The aerial view of the rock shows a semi-circular shape, which was affected by geological weathering. The northwest slope part of Danigala inselberg has interesting petroglyphs discovered in Chithra Lena $\left(7^{\circ} 41^{\prime} 0.44^{\prime \prime} \mathrm{N} \mid 81^{\circ} 12^{\prime} 45.66^{\prime \prime} \mathrm{E}\right)$. These symbols are relatively new and, for the first time, discovered in Sri Lanka during an archaeoastronomical survey conducted by Eco Astronomy Sri Lanka in a corporation with Central Cultural Fund (Polonnaruwa-Alahana Parivena Project). These petroglyphs, now perceived and assessed as art, are mute science prints of ancient cultural vestiges of a bygone society. The predominant forms found are partially similar with few forms found in some sites in Sri Lanka, but with distinct differences in the engraving process. Notably, samples of the bind rune coding of Danigala petroglyphs are quite similar to bind rune's symbols of Shamanic cultures. Besides, the engraving technique is remarkably similar to the technique used in the petroglyphs of Edakkal Caves in India. This paper is an attempt to document and analyze this bind rune coding in purpose to uncover the archaeoastronomical meaning and the historical beliefs.
\end{abstract}

Keywords: Danigala, Circular Rock, Petroglyphs, Bind codes, Sri Lanka Archaeoastronomy. 


\section{Introduction}

Danigala contains an enormous wealth of geodiversity, rich with geological and geomorphological formations dating from as far back as the Precambrian era. These features have been a treasure trove of discovery in the fields of archaeology, astronomy, biodiversity, and cultural artefacts. On 28 July 2020, a new type of petroglyph was discovered at Danigala Circular Rock alongside featuring other engraved symbols. Some of the engraving symbols are recessively close to the linear compounds found in Dorawakakanda cave and Hakbelikanda cave (Somadeva 2012). However, none of the petroglyphs discovered is systematically similar to any previous petroglyphs discovered so far in Sri Lanka. We theorize that the petroglyphs are bind runes coding that present extraordinary value to ancient anthropomorphic research. Although we noticed some resemblance between the petroglyph's symbols and bind coding, the symbols discovered at Danigala Circular Rock show similarities to the Funnel Beaker Culture's stone slabs discovered in Sweden By Burenhult and his team (Burenhult 1981; Larsson 1985; Larsson 1992). These stone slabs originate from a settlement layer belonging to the Early-Middle Neolithic transition (c. 5200 BP) at Hindby Mosse, Western Scania, Sweden (Burenhult 1981; Burenhult 1982). In this, the rock art discovered at Danigala shows clear distinctions from other examples found in Asia. The rock art found in Cheonjeon-ri rock engravings in Korea features images depicting nature, represented as transformed geometric shapes (Jang 2003). Recent discoveries from Russian Far East have revealed similar rock art sites, dated between 14,000-13,000 BP and Sikachi-Alyan; 13,000 BP. These sites revealed in the Amur-Ussury Show a specific iconographical style. Rock Art in Far Eastern Russia (Devlet 2016), similar to the Danigala petroglyphs. Also, the typicality of the engraved rock art throughout Lianyungang includes whereas cup-shaped cupules are mainly in Jiangjunya; and other cupules are mostly "shallow cupules" which is associated with upper Neolithic people culture in the Southeastern Coast of China (Wenjing 2019). Moreover, a cluster of around 200 engraved boulders was discovered near $\mathrm{Sa} \mathrm{Pa}$ in Lao Cai province, a popular resort town previously colonized by France located in the northwest of Vietnam. 
The highland environment, similar to many European climates, is still inhabited by the highland Hmong people. These petroglyphs found near $\mathrm{Sa} \mathrm{Pa}$ in Lao Cai province belongs to the late iron age (Lao Cai and Ha Giang Provinces, Northern Vietnam: Engraved Boulders ) (Tan 2013). Relevant to the South Asian region, Edakkal caves, Wayanad, Karnataka in India representing unique engraved bind runes coding, which approximately date back to the Middle Neolithic era (Kumar 2013). Many types of petroglyphs partially or dominantly correspond to some of the bind codings of Dhanigala Chiththra Lena's petroglyphs. We are looking to document this discovery via brief and systemic processing.

\section{Methodology}

\section{Study area}

Danigala Circular Rock [ Lat: $7^{\circ} 40^{\prime} 50.24^{\prime \prime N}$ | Lon: $81^{\circ} 12^{\prime} 48.32 " \mathrm{E}$ ], a unique geological rock situated near Kandegama in the Polonnaruwa district. We surveyed the northwest slope of Danigala inselberg on July 28th of 2020 ( $7^{\circ} 41^{\prime} 0.44 " \mathrm{~N}$ | $81^{\circ} 12^{\prime} 45.66^{\prime \prime E ~ \mid ~ a l t i t u d e ~} 278 \mathrm{~m}$ ), recording geographical coordinates by GPS device.

\section{Monitoring Strategy}

Our team used a Sony Alpha 58 camera with a resolution of 5456 x 3632 pixels with RAW format capabilities, allowing for a wider room in photo post-processing. The rock artwork found there was carefully measured using a ruler and photo stitcher app for further analysis.

\section{Cluster analysis}

Both the pictures and the measurements were firstly compared with rock art found at other sites in Sri Lanka. The team decided to extend the comparison process to other petroglyphs sites discovered previously in Asia, Europe and Africa, including samples of bind coding. We relied mainly on systematic comparisons of petroglyph geometrics and the process of engraving technique used. Relative dating was established through geological and prehistoric data 


\section{Geological Setting around Danigala Circular Rock}

Danigala Circular Rock is an inselberg of isolated rocky outcrops generally consisting of Precambrian formations (fig. 2). This unique harbour station is geologically situated in the Vijayan Complex; a part of the geological subdivision of Sri Lanka (fig.1). Vijayan Complex includes, amphibolite-facies suite mainly consists of amphibolite facies granitoid gneisses, migmatites, minor meta-sedimentary xenoliths and calc-silicate rocks (Cooray 1984, 1994; Dahanayake and Jayasena, 1989). Partially called bare rock mounds or turtleback shaped inselbergs are scattered in the II - Second Planted Surface (Katupotha, 2013). This kind of inselberg (fig. 2) has shown great resistance to erosion due to its composition of granitic rocks containing large proportions of quartz, one of Earth's toughest rock-forming minerals.

\section{Images and Preliminary Reading}

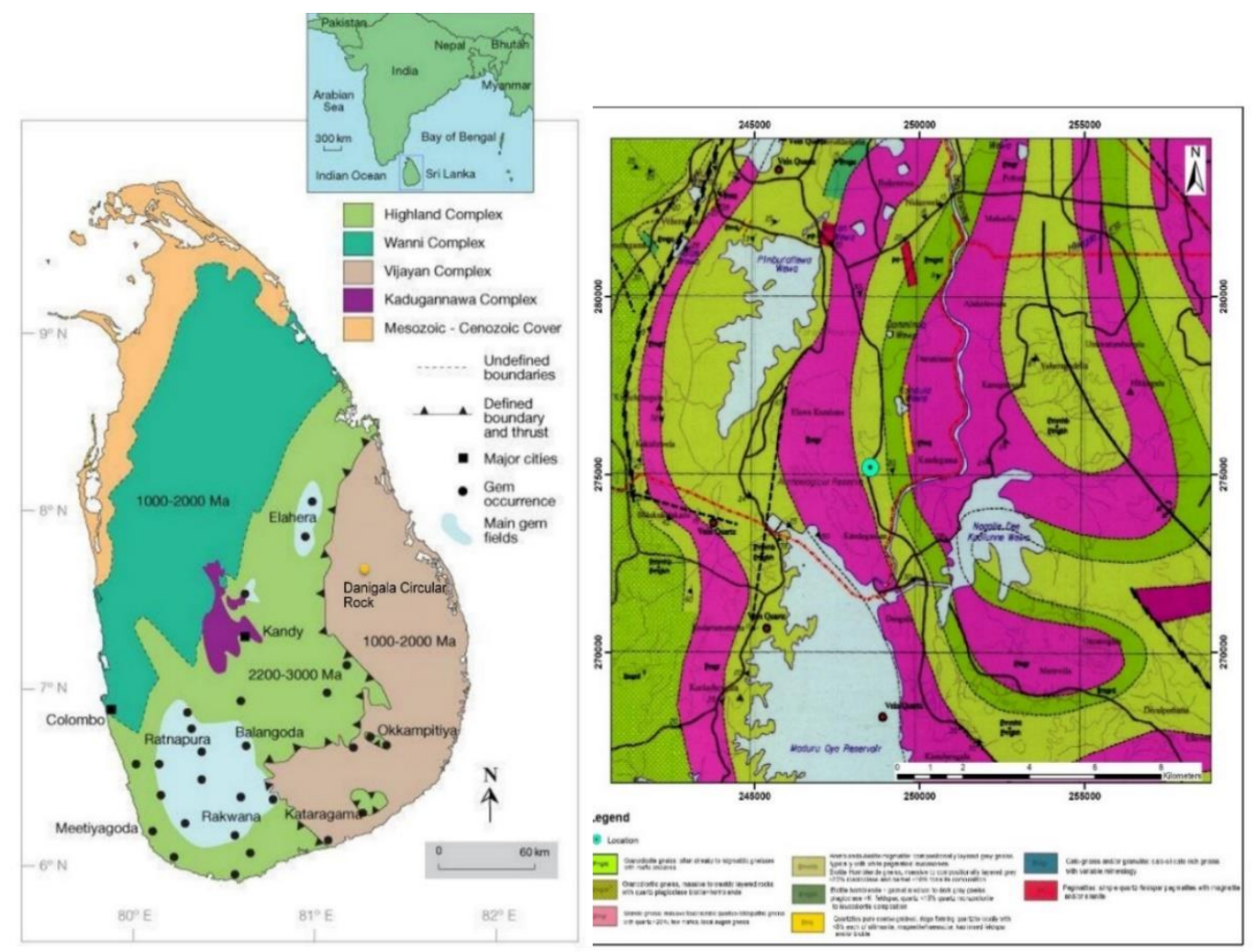

Fig.1. (Right) Depicts the Main Geological Zones, includes relative dating (left side) (CCooray 1984). Map showing the lithotectonic subdivision of Sri Lanka (After Cooray, 1994). 


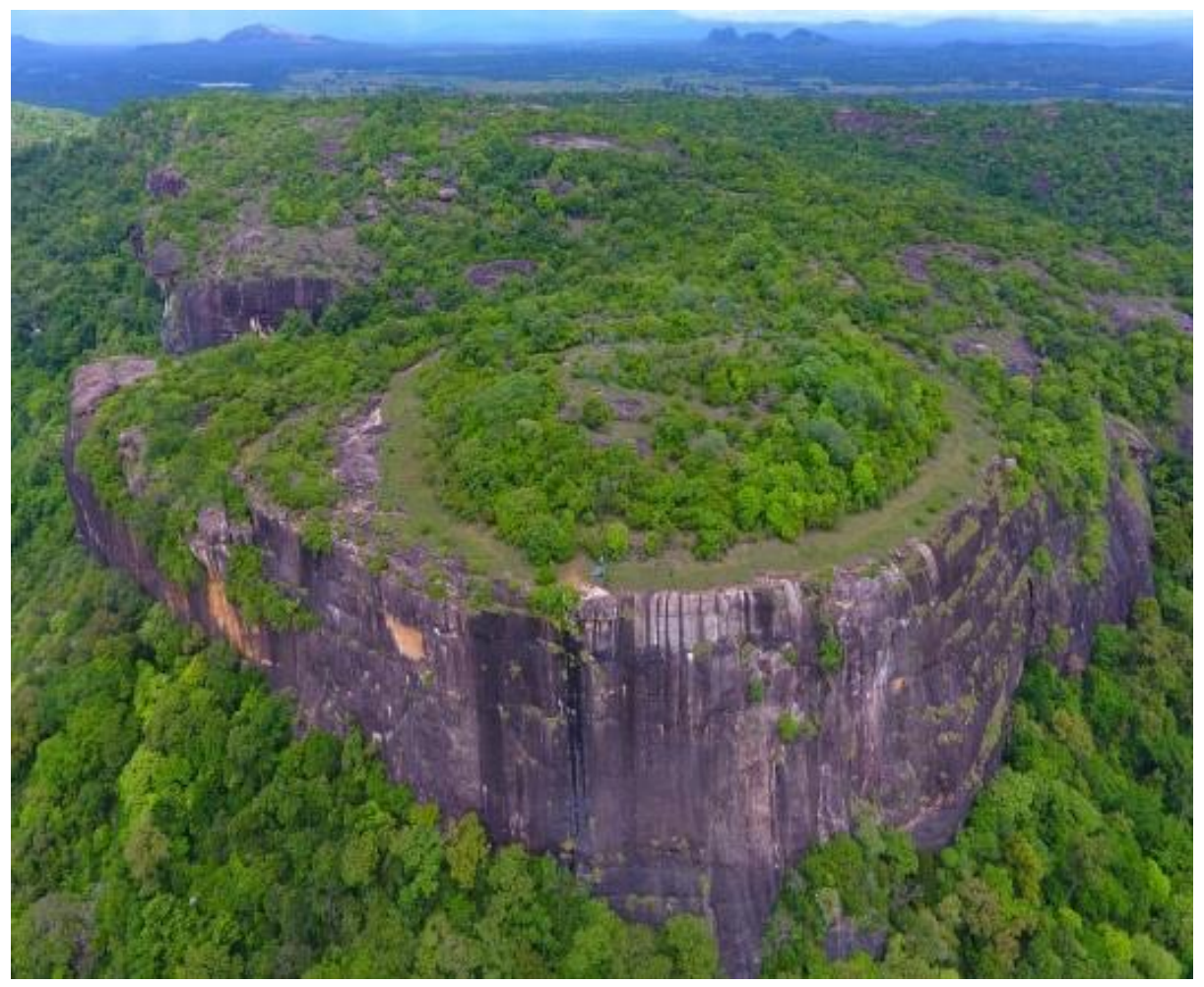

Fig. 2. Aerial view of Danigala Circular Rock (Image () Eco Astronomy SL and CCF-

Polonnaruwa).

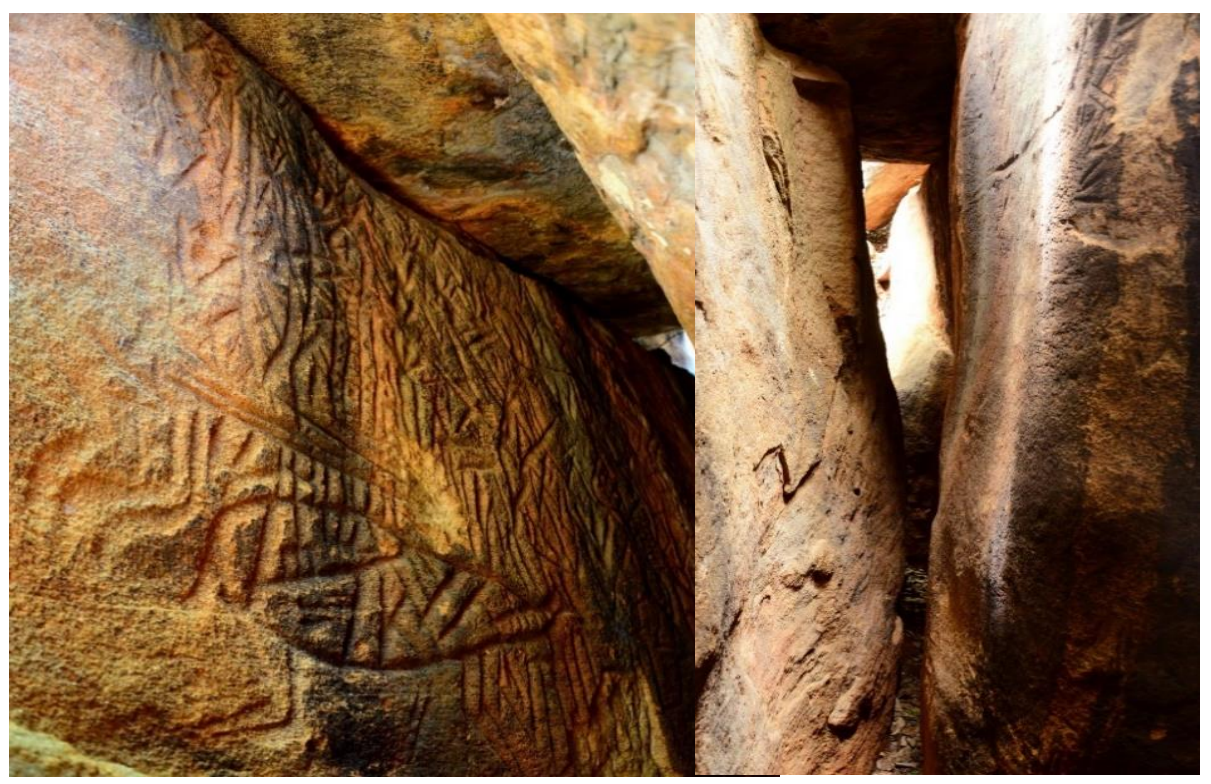

Fig.3. (Left) Danigala Chithra Lena - 


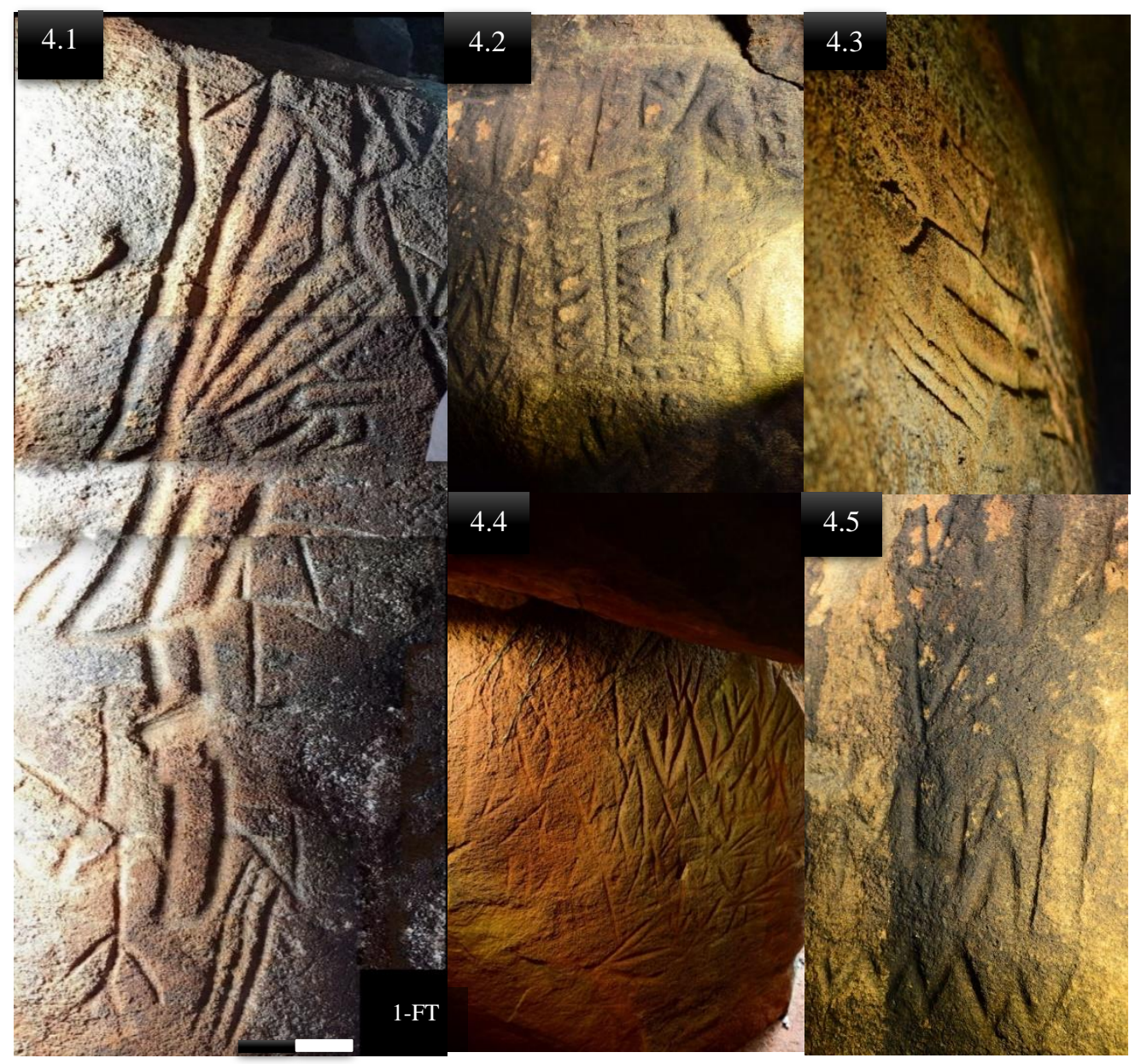

Fig.4.1. One of the complete petroglyphs found in the Left side wall, representing anthropomorphic figures (Image () Aravinda Ravibhanu) $\mid$ Reconstructed image via photo stitching app.

Fig.4.2. Left side wall at the middle of the liner chamber representing anthropomorphic figures like ladders (Image @CCF-Polonnaruwa and Eco Astronomy SL).

Fig.4.3. The left side wall of the liner chamber representing anthropomorphic figures like bows \& arrows (Images $\odot$ CCF-Polonnaruwa and Eco Astronomy SL).

Fig.4.4. Left side wall at the dead-end of the liner chamber representing anthropomorphic figures (Image (CCCF-Polonnaruwa and Eco Astronomy SL).

Fig.4.5. The left sidewall of the liner chamber representing anthropomorphic figures like crooked bind runes (Images @CCF-Polonnaruwa and Eco Astronomy SL). 


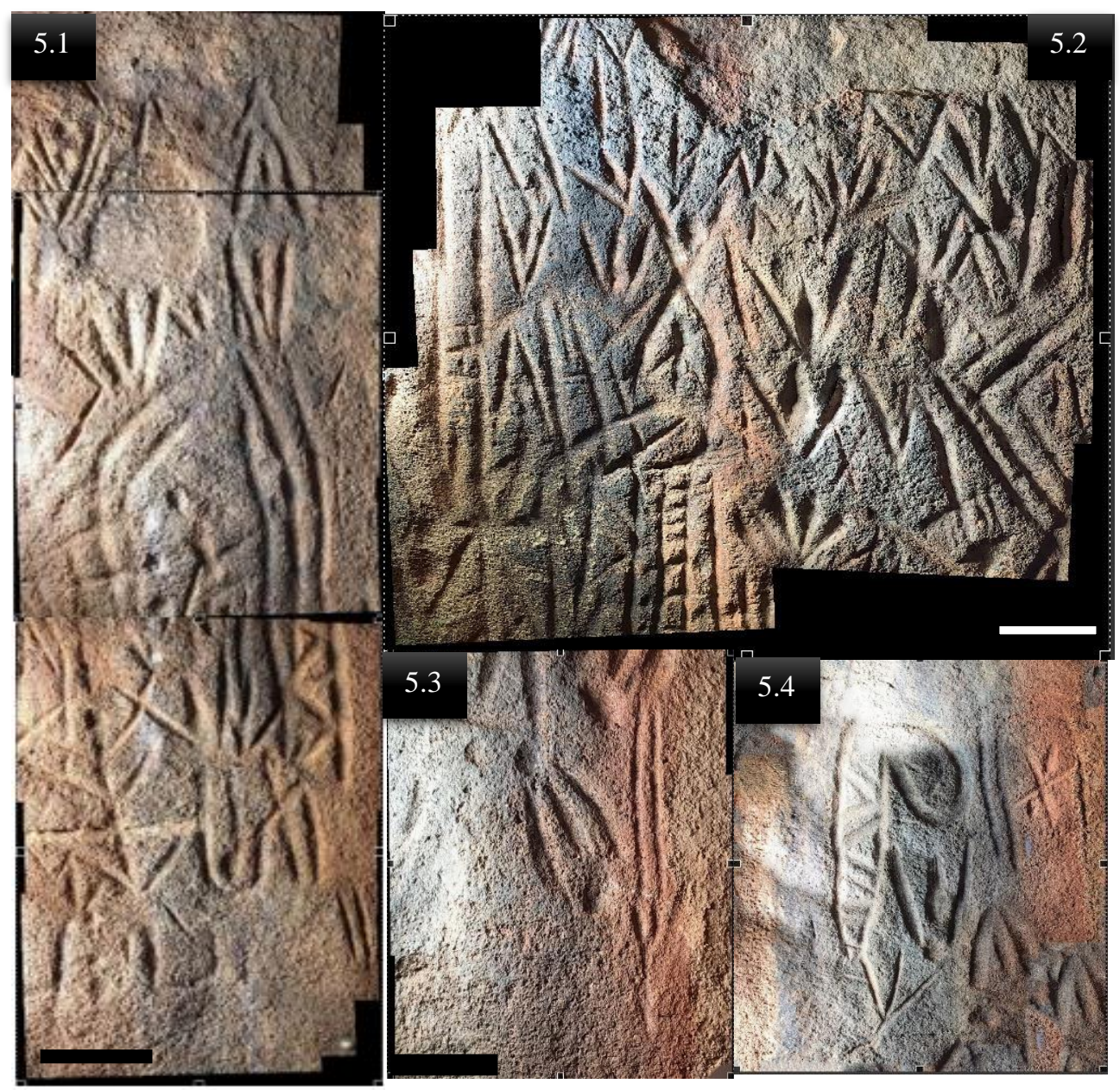

5.1. Complete petroglyphs at the left side wall, representing anthropomorphic figures of a group of healers, visits friends and dreams $\mid$ Bind Code (Image @ Aravinda Ravibhanu).

5.2. Complete petroglyphs at the left side of the wall, representing anthropomorphic figures of worshipping and ladder technique of human spiritual activities (Image @ Aravinda Ravibhanu).

5.3. Complete petroglyphs discovered at the left side wall, representing anthropomorphic figures of blessing hunter (Image () Aravinda Ravibhanu).

5.4. Bind code representing injured human trying to self-healing, worshiping, and sacrifice or giving to giant marabou stork (extinct)? or bird of Accipitridae family (need more citations) (Image () Aravinda Ravibhanu 


\section{Results}

The Danigala rock-shelter contains an extraordinary variety of petroglyphs symbols similar to those found in Edakkal Caves, Wayanad, Karnataka in India. These petroglyphs have not yet been entirely decoded or assembled into a single image. In the left wall of Danigala Chithra Lena, we discovered a clear representation of the first petroglyph (fig. 3-5.4) and the engraving symbols composition are similar to the petroglyphs encountered in Edakkal Cave. The petroglyph's wall, approximately $25 \mathrm{ft}$ $\mathrm{x} 16 \mathrm{ft}$ including the left side of the single linear chamber, has suffered from weather erosion (fig. 3 right). The distances between the two granitic walls of the linear chamber have represented less than $30 \mathrm{~cm}$ width via the bottom of the shelter. Individual boulders can be seen on the top of the walls as a sort of hood; similar to the shelter Danigala Chithra Lena but not fully open to the sky (fig. 3) like the case observed in Edakkal Cave. These types of geological formations are natural caves that may have formed after earthquakes or by slower erosive processes (Shyju, 2016). Most of the engravings are found only on the left side of the rock shelter walls, containing figures which at first glance to be humans, peacocks? or Giant marabou stork (extinct) ? or bird of Accipitridae family, plants, dogs, ladders, arrows, bow, and geometric signs (Need more decoding and analysis) (fig. 3-5.4). Some of the geometric signs and bind code may represent counters related to astronomical symbols (Taylor, 2017). At the terminus of the same chamber, there is another petroglyph (left side) as a separate wall, with multiple additional anthropomorphic fingers, what appears to be an incomplete ladder, animals, and plants (fig. 4.2 and 5.2). We hypothesize that the two granitic walls belong to the same rock which has been separately affected by geological weathering. We believe that the complete decoding of the petroglyphs will be quite challenging due to the variety of shapes and symbols at this site. 


\section{Discussion \& Conclusion}

The people who created the engravings did not execute it as a work of art as we perceive it today. It was a reflection of their beliefs and practices. Its true meaning will likely remain a mystery for the foreseeable future beyond the interpretations we can make. We observed that these bind runes show similarities between those found at Aztec and Shamanic (Indian) cultural sites. We've identified a few possible, generalized interpretations of some bind runes as Mastermind, Day, Possession, Open, Crooked, Animals, Humans, Plants, Birds, Bow and arrows, Self-healing, Dreams, Giving, Purifications, (fig. 3- 5.4). This area was likely a place of worship and veneration for the Neolithic and Megalithic aboriginals who once inhabited the region. Considering the dating of similar engravings processed and discovered out of Sri Lanka, the ruins likely date to around relatively represent 5,000-3,500 BP. The main anthropomorphic figures at Danigala do not appear to be carved with pure or traditional beliefs and iconography of the gods worshipped in the temples. Instead, they appear to be reflective of a ritual system built around beneficial ancestral spirits who could be approached and appeased in exchange for protection from evil spirits, diseases, and calamities. The petroglyphs might also represent deities of the Vedda people at Girigama as symbols of ritualistic offerings. Many of the symbols carved adjoining the main figure has a votive value, some possibly denoting death and the transmigration of the soul into the afterlife. Other symbols include anthropomorphic representations of animals. These animals were totems of the Girigama Vedda or Danigala Vedda-Girigama being the ancient name for the Danigala area. Anthropomorphic figures of Danigala Chithra Lena Petroglyphs though linear in delineation, are quite articulate in execution. The outline of the figures appears to have been first outlined and subsequently etched or grooved out afterwards. Most of the figures are generally made using single grooved lines, though figures with grooved double lines were also encountered.

The double-engraved lines of the Danigala Chithra Lena Petroglyphs appear to be an engraving method unique to its creators. Recent studies have concluded that the local Kurumba tribesmen living near the area have no explicit attachment to or reverence 
for these engravings, suggesting that an outside group was responsible for the Eddakal engravings. There was some possible level of migration between Sri Lanka and India via the Adam's Bridge sandbar, in consideration of the many fluctuations of sea level during the late Holocene around the Sri Lankan region. Some possible dates representing periods when sandbar was partially open include: $5830 \pm 90$ and $6000 \pm 90 \mathrm{BP} \mid 5590 \pm 80$ and $5840 \pm 80 \mathrm{BP} \mid 5910 \pm 70$ and 5600 $\pm 70 \mathrm{BP} .19$ Focusing on average fluctuations in South Asia, around 11,500 yr BP-12,800yr BCE, this was the most dominant period of migration. As the relative sea level has been dropped by more than $25 \mathrm{~m} \pm 5 \mathrm{~m}$ on average from current sea levels, we believe that the Adam's Bridge sandbar must have been dominantly opened during this time. Curiously, representations of ladders or stretchers were found in multiple instances at this site, wheels found to be absent (Eddakal has bind ruins of wheels). To draw an analogical systematic comparison with Buddhist art, the representation of Buddha's descent from heaven is also represented by a series of steps. Recently research has photodocumented evidence of bamboo stretchers or ladder-like objects used in the present day by the Kadar tribe group in Kerala to transport the deceased to the burial ground. Such ladder imagery was quite usually represented amongst Vedda and other tribes as well.

This stretcher would then be was abandoned over the grave along with other utilitarian objects, and over the head portion of the deceased would be planted a stone. It is interesting to note that most of these emblems are found adjoining and directed towards the most substantial anthropomorphic figures as though in reverence to it. The connection between ladder engravings with death and the afterlife, as well as a potential connection with later Buddhist imagery, is highly worth further investigation.

The location of the Danigala inselberg itself is awe-inspiring - there is a mystic feel to the ruins that was felt even during its examination. Deeper exploration of the burial pits, microlithic, potteries, and other prehistorical factors, can provide new directions to the archaeological studies in this area. Further study of the runes is necessary to determine any deeper meaning. These petroglyphs remain as mute cultural vestiges, 
archaeoastronomical artefacts of a bygone society now perceived and assessed as art. Behind the art lie the religious beliefs of its practitioners and creators, as of yet unseen in the modern-day. As the creators of the glyphs have disappeared from the area, the true beliefs and meanings envisaged by its creators will likely remain obscured in mystery to modern researchers. Nevertheless, the site and its bygone creators remain a fascinating topic of inquiry, for which future studies are certainly warranted.

\section{Acknowledgement}

Our Sincere thanks go to all the members of Center Cultural Fund -Polonnaruwa includes, Prof. Gamini Adhikari (Director General of CCF ), Prof Senarath Dissanayake(Director General of Department of Archaeology, Sri Lanka ), Mrs U.G.Chandralatha ( Project Manager-CCF Polonnaruwa). Also, We are thankful to Mr. G.Wijitha Nanda Kumar ( Additional Secretary - National Heritage- Ministry of Buddhasasana, Religious and Cultural Affairs) and $\mathrm{Mr}$ Prasad Ranasinghe (Deputy Director-National Heritage- National Heritage- Ministry of Buddhasasana, Religious and Cultural Affairs). Special thanks go to Rev. Kandegama Deepavanshalankara (Kandegama Dhananjya Rajamaha Viharaya) and Prof. Karunasena Hettiarachchi (Department of History \& Archaeology -University of Sri Jayawardhanapura) for the share their ideas via preliminary discussion. I also much appreciate the technical support of Mr. Janaka Prasanna who ia the research assistance of the Eco Astronomy Sri Lanka and EASL Co support hubs of the USA, Romania, India, China and Singapore.

\section{References}

Burenhult, G. 1981. “Stenåldersbilder. Hällristningaroch stenåldersekonomi.” Stockholm: Stockholm University.

Burenhult, G. 1982. “Arkeologi i Sverige, Bind 1.” Höganäs.

Cooray, P.G. 1984. “An Introduction to the Geology of Sri Lanka (Ceylon).” National Museum of Sri Lanka, Colombo: 340. 
Cooray, P.G. 1994. “The Precambrian of Sri Lanka: a historic review. In: Raith, M., Hoernes, S. (Eds.), Tectonic Metamorphic and Isotopic Evolution of Deep Crustal Rocks, with Special Emphasis on Sri Lanka." Precambrian Research 66: 3-18.

Cunningham, A. 1879. "The Stûpa of Bharhut: A Buddhist Monument Ornamentedwith numerous sculptures illustrated of Buddhist legend and history in the third century B.C." Indological Book House in Varanasi xiii, vii, 143 p.

Dahanayake, K., H.A.H. Jayasena., B.K. Singh., R.S. Triwari., and Tripathi. 1989. “A PermoTriassic Plant Microfossil Assemblage from Sri Lanka, Review of Paleobotany and Palynology." 58:197- 203.

Dahanayake, K., N. Kulasena., G.V. Prasad., K. Dutta., and D.K. Ray. 2011. "Sedimentological and 14C dating studies of past tsunami events in Southern Sri Lanka." Natural Hazards, 63(1):197-209.

Devlet, E. G., and A.S. Pakhunov. 2016. "Rock Art Studies in Northern Russia, the Urals and the Far East 2010-2014." Rock Art Studies: News of the World v, 97-114.

Fawcett, F.1901. "Notes on the rock carvings in the Edakkal caves, Wayanad." Indian Antiquary 30:409-421.

Hettiarachchi, K. 2020. “An inscription reading behind the Dhanigala Dhananjiya Rajamaha Viharay,,Kandegama.” (Unpublish).

Jang, Seog Ho. 2003. "Survey Report on National Treasure No.147 Cheonjeon-ri Square Stone, Ulsan." Korea's Prehistoric Art Research Center.

J, S. P. 2016. “A Study on Heritage Preservation and Tourism Development at a Prehistoric Site in Kerala Through Community Engagement." SSRN Electronic Journal.

Katupotha, J. 1989. "Coastal landforms during the Holocene Epoch in Sri Lanka: are they comparable to those in Brazil and Venezuela, Ext. Abs." International Symposium on Global changes in South America during the Quaternary, Sao Paulo (Brazil) 188-191.

Katupotha, J. 1988a. "Hiroshima University Radiocarbon Dates 1: West and South Coasts of Sri Lanka." 30(1): 125-128. 
Katupotha, J. 1988b. "Hiroshima University Radiocarbon Dates 1: West and South Coasts of Sri Lanka.” 30 (3): 341-346.

Katupotha, J. 2013. "Palaeoclimate change during Glacial Periods: Evidence from Sri Lanka Journal of Tropical Forestry and Environment.” Survey Department of Sri Lanka, 2007: National Atlas of Sri Lanka 3(1): 42-54.

Katupotha, J. 2013. "Planated Surfaces and Erratic Boulders of Sri Lanka." Proceedings of 29th Technical Sessions of Geological Society of Sri Lanka 91-94.

Kumar, A. 2013. "Decoding the meaning and beliefs associated with petroglyphs in Edakkal rock shelter, Kerala, India.” xxv Valcamonica Symposium 337-342.

Kurian, B. 2013. "Mahadevan, Iravatham. 1998." The Earliest Inscriptions of Kerala Presidential Address xxiv Annual congress of the Epigraphical Society of India held at Trichur.

Larsson, L. 1985. “En kustboplats från tidlig bondestenalder i södra Skåne.” Ale 4: 1-14.

Larsson, L. 1992. "Neolithic Settlements in the Skateholm Area, southern Scania." Meddelanden från Lunds Universitets historiska museum 5-44.

Premakumara, De Silva., and A. Punchihewa. 2011. "Socio- Anthropological Research Project on Vedda Community in Sri Lanka." Journal of Ministry of Cultural Affairs, Sri Lanka.

Mann, T., M. Bender., T. Lorscheid., P. Stocchi., M. Vacchi., A. Switzer., and A. Rovere. 2019. "Relative sea-level data from the SEAMIS database compared to ICE-5G model predictions of glacial isostatic adjustment.” Data in Brief, 27, 104600.

Somadeva, R. 2012. "Rock Paintings and Engraving Sites in Sri Lanka." Colombo: Postgraduate Institute of Archaeology.

Sumanarathna, A.R., B. Madurapperuma., J. Kuruppuarachchi., J. Katupotha., S. Abeywardhana., and P. Jayasinghe. 2016. "Morphological Variation and Speciation of Acavidae Family: A Case Study from Fossil and Living Species of Batadombalena Cave Prehistoric Site in Sri Lanka." Annals of Valahia University of Targoviste, Geographical Series 16(2): 59-68.

Sumanarathna, A.R. 2016. “Geology of Sri Lanka.” Journal of Eco Astronomy Sri Lanka Special report. 
Sumanarathna, A.R. 2020. “Geology of Sri Lanka.” Journal of Eco Astronomy Sri Lanka Special report -02 .

Sumanarathna, A.R., A. Bandara., J. Katupotha., and M. Aouititen. 2020. “Archaeoastronomy Sri Lanka." Journal of Eco Astronomy (2020). Special report03.https://www.researchgate.net/publication/344097947_Danigala_Coding_Sri_Lanka

Sumanarathna, A.R., et al. 2017. "An Assessment Of Geological Formation Of The RakwanaPannila Mountain Of Sri Lanka.” Journal of Eco Astronomy (2017), 1(1): 32-42.

Sumanarathna, A.R., J. Katupotha., K. Rajapaksha., and M. Aouititen. 2020. “Comparative Systematic Analysis of Proxy to Indicate Younger Dryas Cooling in Late Pleistocene in Sri Lanka.” Research Symposium 2019: The Ocean University of Sri Lanka.

Taylor, B. 2017. “BEFORE ORION: Finding the Face of the Hero.” Kindle Edition (Kindle Edition ed., Ser.5). Aquila Media Group 1-598.

Tan, N. H., and P.S. Taçon. 2013. "Rock Art and the Sacred Landscapes of Mainland Southeast Asia." Rock Art and Sacred Landscapes, 67-84.

Wenjing, Zhang. 2019. "Rock Art in Northern China, Eastern China and Mongolia. Edited

Clottes, Jean \& Smith, Benjamin (2019) Rock Art in East Asia: A Thematic Study." Documentation. ICOMOS International, Paris, 148p. ICOMOS Thematic studies, ISBN 978-2-918086-27-7 (e-book). 